\title{
Mechanical Behaviour of Light Weight Concrete Panels
}

\author{
E. Prabakaran, G. Krishnaraaju, M. Nithya, D. Narsamma
}

\begin{abstract}
Light weight concrete (LWC) Playing a primary position in lowering the useless weight of the shape as properly as it meets the goals of load-bearing man or woman in some cases. LWC manufacture distinct in keeping with the use and availability of materials offers the freeness in concrete design blend. LWC advanced person including sound insulation, thermal resistivity and power lead for more use of the product. This paper deals LWC research at the partition panels with interlocking gadget to boom shear and flexural conduct compared to normal gypsum board partitions. The LWC gives more desirable energy at $0,050 \%$ in every of the aluminum and gypsum addition as compared to zero.0.5\% in the cement substitute.
\end{abstract}

Keywords: LWC (light-weight concrete), sturdiness, each panel, aerated, aluminum.

\section{INTRODUCTION}

Of studies within the concrete industry, using structural components used are getting extra concrete. In the framed shape, partitions generate greater load equal to the burden value of lifestyles. To reduce the lifeless load, the partition can in lightweight concrete. Prefabrication and simple structural modeling for this factor reduces the time and one economically for quicker creation. Despite the heavy concrete bear minimum electricity of light inside the press, the potential in shear and flexural conduct wishes to enhance inside the partition panel. Lightweight concrete material may be carried out via low density or low density techniques which include by way of using a concrete production lightweight combination, concrete primarily based foam, concrete excessive air, no fines concrete. Fibers utilized in lightweight concrete to maintain the metallic from corrosion to resist towards chlorides and other exposure conditions, to be able to bring about minimum price burden to maintenance3. For stuctural and non-structural concrete dead load is decreased via the usage of lightweight concrete that will increase worlk form design and material discount occurs. Lightweight concrete typically has a density of about three hundred - $1850 \mathrm{~kg} / \mathrm{m} 3$ and has a thermal and sound insulating properties have been suitable. LWC produce better skid resistance, the capacity of Sound Transmission (forty\%), Air permeability2.

Revised Manuscript Received on September 14, 2019.

E. Prabakaran, Assistant Professor, Department of Civil Engineering, Dr.N.G.P. Institute of Technology, Coimbatore, Tamil Nadu, India. (Email: onlinepraba@gmail.com)

G. Krishnaraaju, Assistant Professor, Department of Civil Engineering, Dr.N.G.P. Institute of Technology, Coimbatore, Tamil Nadu, India.

M. Nithya, Professor, Department of Civil Engineering, Siddhartha Institute of Technology and Sciences, Hyderabad, Telangana, India.

D. Narsamma, Assistant Professor, Department of Civil Engineering, Siddhartha Institute of Technology and Sciences, Hyderabad, Telangana, India.
The paper gives is vital to determine the overall performance of light-weight foamed concrete through including numerous chances of aluminum powder as an agent entrapped and determine numerous mechanical electricity and determine the effect of using extraordinary chances of aluminum powder and behavior of each bending mild weight concrete panels. Artificial foam used for the density of beneath $1000 \mathrm{~kg} / \mathrm{m} 3$ for the low fine concrete foam (Brady \& Jones, 2001) 1.

\section{INVESTIGATIONS IN LIGHTWEIGHT CONCRETE}

Using lightweight panels in buildings has a giant role to lower useless load and seismic load induced. From an economic standpoint, the usage of a lower amount of fabric because of a lower in the dimensions of the structural elements. On the alternative hand, use a lightweight panel with thermal insulation properties, reducing the cost of overall performance, efficiently.

The substances had been taken to supply light-weight concrete have been on the advice of researchers formerly and materials are cement, excellent mixture, chemical additives in (Table 1 - aluminum powder and gypsum in the ratio of zero.0.5\%, $0.050 \%$ and zero.0.5\%) Percentage of the volume of semen taken,

Figure 1 and Figure 2 show the aluminum powder and gypsum used inside the practise of light-weight concrete. Table 2 and Table three provides the propertiues of aluminum and gypsum and Table four suggests the weight of the pattern unit LWC.

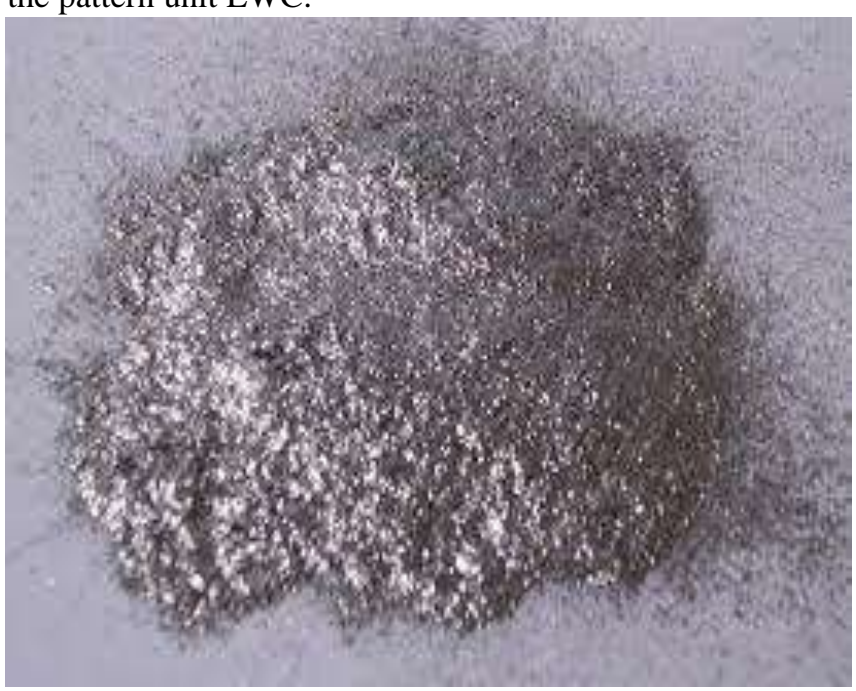

Figure 1 Aluminium powder

Published By: Blue Eyes Intelligence Engineering 


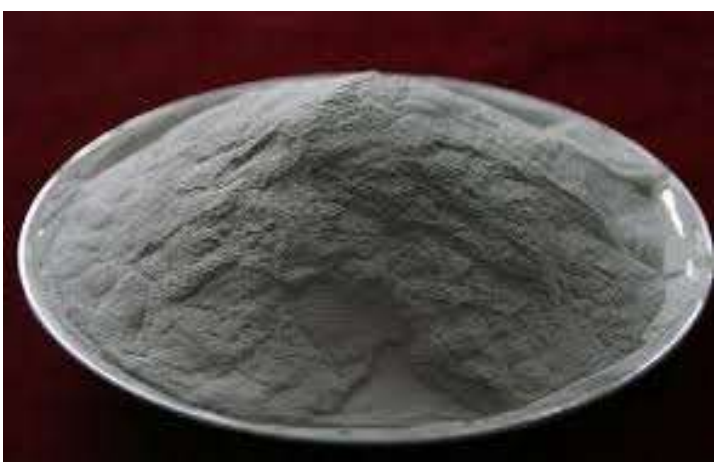

Figure 2 Gypsum

Table: 1 Mix Designation for the Specimens:

\begin{tabular}{|c|c|c|}
\hline \multirow{2}{*}{$\begin{array}{c}\text { Mix } \\
\text { designation }\end{array}$} & \multicolumn{2}{|c|}{$\begin{array}{c}\text { \% replacement of } \\
\text { cementwih }\end{array}$} \\
\cline { 2 - 3 } & $\begin{array}{c}\text { Alumini } \\
\text { um }\end{array}$ & $\begin{array}{c}\text { Gyps } \\
\text { um }\end{array}$ \\
\hline $\mathrm{S}$ & 0 & 0 \\
\hline $\mathrm{S}_{1}$ & $0.025 \%$ & $\begin{array}{c}0.025 \\
\mathrm{~m}\end{array}$ \\
\hline $\mathrm{S}_{2}$ & $0.050 \%$ & $\begin{array}{c}0.050 \\
\mathrm{~m}\end{array}$ \\
\hline $\mathrm{S}_{3}$ & $0.075 \%$ & $\begin{array}{c}0.075 \\
\mathrm{n}\end{array}$ \\
\hline
\end{tabular}

Table 2 Properties of Aluminum Powder:

\begin{tabular}{|c|c|}
\hline Properties & Values \\
\hline Physical state & Powder \\
\hline Appearance & Silver gray \\
\hline Odour & Odourless \\
\hline $\mathrm{pH}$ & not available \\
\hline Boiling point & $2467^{\circ} \mathrm{C}$ \\
\hline Melting point & $660^{\circ} \mathrm{C}$ \\
\hline Solubility & Insoluble \\
\hline Specific gravity & $2.7020 \mathrm{~g} / \mathrm{cm}^{3}$ \\
\hline Molecular formula & $\mathrm{Al}$ \\
\hline Molecular weight & 26.98 \\
\hline
\end{tabular}

Table 3 Properties of Gypsum:

\begin{tabular}{|c|c|}
\hline Properties & Values \\
\hline Physical state & Powder \\
\hline Appearance & $\begin{array}{l}\text { colourless } \\
\text { to white }\end{array}$ \\
\hline Molecular formula & $\begin{array}{c}\text { CaSO4.2H } \\
2 \mathrm{O}\end{array}$ \\
\hline Specific gravity & $2.31-2.33$ \\
\hline Odour & Odourless \\
\hline Melting point & $1460^{\circ} \mathrm{C}$ \\
\hline
\end{tabular}

\section{MIX DESIGN}

1:2 has been taken the mix design from the literature assessment with the aid of Dhawal Desai-IIT Bombay (2000)(four). In this have a look at foamed concrete have been organized for four different sorts with various range of density (1600 - $1760 \mathrm{~kg} / \mathrm{m} 3)$. From the Table 4, specimen 2 having low density and shape that the workability take a look at had been taken for diverse w/c ratio and the effects had been shown in Table 5 .

Table 4 Unitweight:

\begin{tabular}{|c|c|}
\hline Sample & $\begin{array}{c}\text { Unit weight of cube } \\
\left(\mathrm{kg} / \mathrm{m}^{3}\right)\end{array}$ \\
\hline S (ordinary concrete) & 2415.60 \\
\hline $\mathrm{S}_{1}($ LWC1 $)$ & 1763.46 \\
\hline $\mathrm{S}_{2}(\mathrm{LWC} 2)$ & 1603.45 \\
\hline $\mathrm{S}_{3}(\mathrm{LWC} 3)$ & 1752.29 \\
\hline
\end{tabular}

Table 5 Tests for workability of concrete:

\begin{tabular}{|c|c|c|c|c|}
\hline $\begin{array}{c}\text { Sampl } \\
\mathrm{e}\end{array}$ & $\begin{array}{c}\text { W/C } \\
\text { ratio }\end{array}$ & $\begin{array}{c}\text { Slump } \\
(\mathrm{mm})\end{array}$ & $\begin{array}{c}\text { Vee- } \\
\text { Bee } \\
(\mathrm{mm})\end{array}$ & $\begin{array}{c}\text { Compaction } \\
\text { factor }\end{array}$ \\
\hline $\mathrm{S} 2$ & 0.4 & 50 & 56 & 0.678 \\
\hline $\mathrm{S} 2$ & 0.5 & 46 & 46 & 0.792 \\
\hline $\mathrm{S} 2$ & 0.6 & 39 & 23 & 0.835 \\
\hline
\end{tabular}

The cubes, prism and cylinder specimens were prepared with foamed concrete which consisting of Sand, cement and foaming agent. Concrete and specimens have been used to measure the physical and mechanical home such as the ability to work, Unfold ability checks, electric press, tensile and flexural strength energy. After recovering enough, foam concrete is stripped from its mold.

\section{LIGHT MECHANICAL BEHAVIOR OF CONCRETE \& RESULTS}

Table 6 shows the press, split tensile and flexural behavior of light weight concrete. Also Tables 7 and 8 show the strength of the effect of the slab and the loading situation for the slab. Table nine shows the deflection plates for a variety of loading conditions..

Table - 6 Mechanical behaviour of Light Weight Concrete:

\begin{tabular}{|c|c|c|c|c|c|c|}
\hline \multirow{2}{*}{$\begin{array}{c}\mathrm{Sa} \\
\mathrm{mp}\end{array}$} & \multicolumn{2}{|c|}{$\begin{array}{c}\text { Compressive } \\
\text { strength, MPa }\end{array}$} & \multicolumn{2}{c|}{$\begin{array}{c}\text { Split tensile } \\
\text { strength, MPa }\end{array}$} & \multicolumn{2}{c|}{$\begin{array}{c}\text { Flexural } \\
\text { strength, MPa }\end{array}$} \\
\cline { 2 - 7 } & $\begin{array}{c}14 \\
\text { days }\end{array}$ & $\begin{array}{c}28 \\
\text { days }\end{array}$ & $\begin{array}{c}14 \\
\text { days }\end{array}$ & $\begin{array}{c}28 \\
\text { days }\end{array}$ & $\begin{array}{c}14 \\
\text { days }\end{array}$ & $\begin{array}{c}28 \\
\text { days }\end{array}$ \\
\hline $\mathrm{S}$ & 14.59 & 21.75 & 1.45 & 2.11 & 2.02 & 5.26 \\
\hline $\mathrm{S}_{1}$ & 3.18 & 6.74 & 0.35 & 0.90 & 0.72 & 1.88 \\
\hline $\mathrm{S}_{2}$ & 5.40 & 8.59 & 0.54 & 1.22 & 0.87 & 3.44 \\
\hline $\mathrm{S}_{3}$ & 4.07 & 8.07 & 0.40 & 1.10 & 0.78 & 2.59 \\
\hline
\end{tabular}

Table 8 Loading condition for slab:

\begin{tabular}{|c|c|}
\hline $\begin{array}{c}\text { Specim } \\
\text { en }\end{array}$ & Description \\
\hline $\mathrm{S}_{2} \mathrm{~T}_{1}$ & Loadig parallel to specimen \\
\hline $\mathrm{S}_{2} \mathrm{~T}_{2}$ & Loading perpendicular to specimen \\
\hline $\mathrm{S}_{2} \mathrm{~T}_{3}$ & Loading parallel to shear plane of specimen \\
\hline
\end{tabular}

Table 9 Flexural strength of slabs at 28 days

Published By 


\begin{tabular}{|c|c|c|c|}
\hline $\begin{array}{c}\text { Speci } \\
\text { men }\end{array}$ & Loading condition & $\begin{array}{c}\text { Flexural } \\
\text { strength of } \\
\text { slabs } \\
\left(\mathrm{N} \backslash \mathrm{mm}^{2}\right)\end{array}$ & $\begin{array}{c}\text { Deflect } \\
\text { ion } \\
(\mathrm{mm})\end{array}$ \\
\hline $\mathrm{S}_{2} \mathrm{~T}_{1}$ & & 24.284 & 6 \\
\hline $\mathbf{S}_{2} \mathbf{T}_{2}$ & & 33.487 & 9 \\
\hline $\mathbf{S}_{2} \mathbf{T}_{3}$ & & 27.868 & 11 \\
\hline
\end{tabular}

From the above test values, we conclude that the specimen $\mathrm{S}_{2}$ has higher strength than other two specimens.

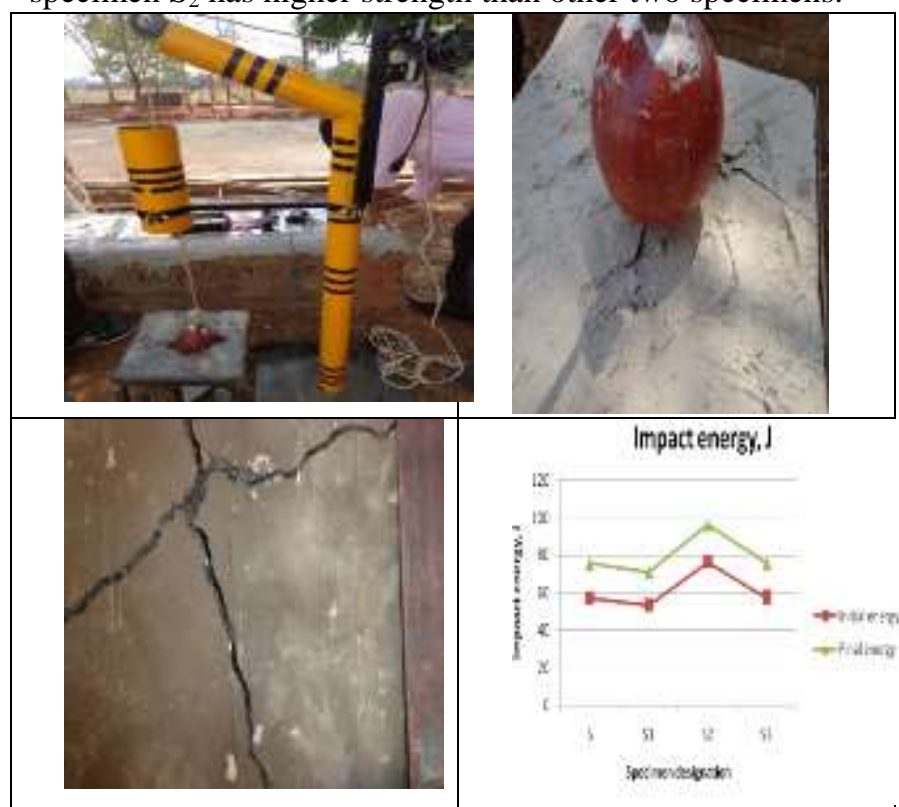

Figure - 7 Impact energy of slabs, J

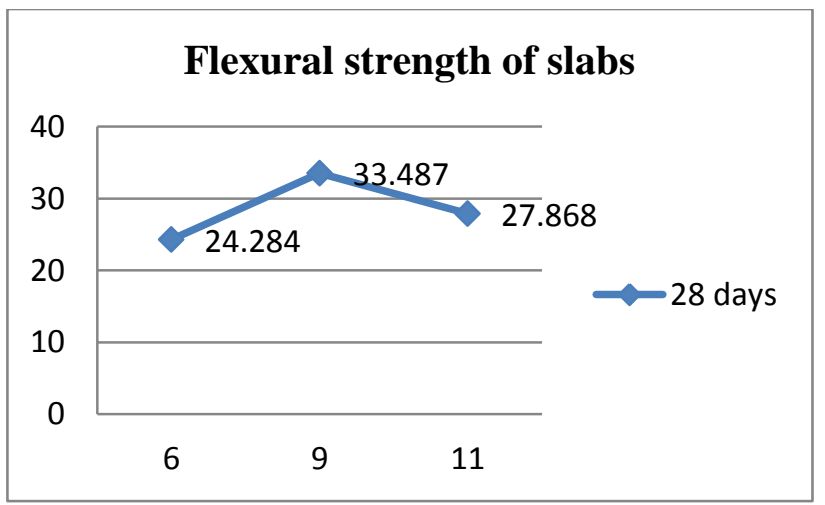

Figure 8 Flexural strength of slabs

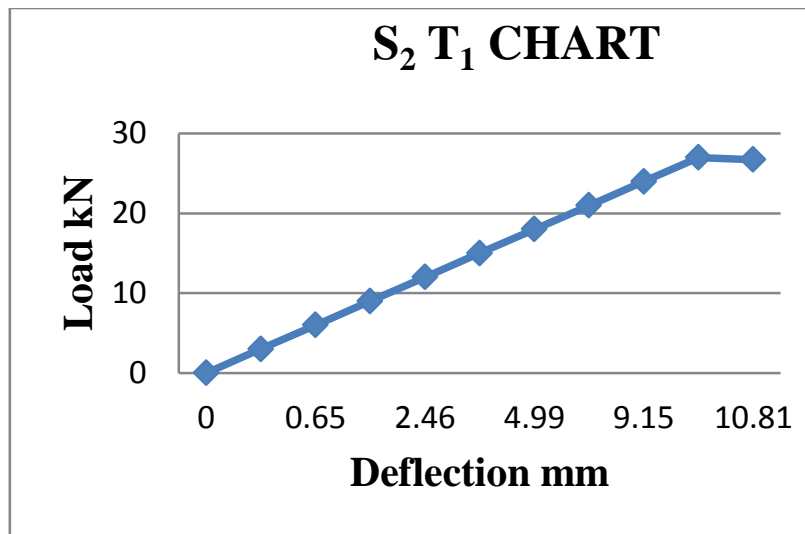

Figure 9 Deflection of slab $S_{2} T_{1}$ CHART

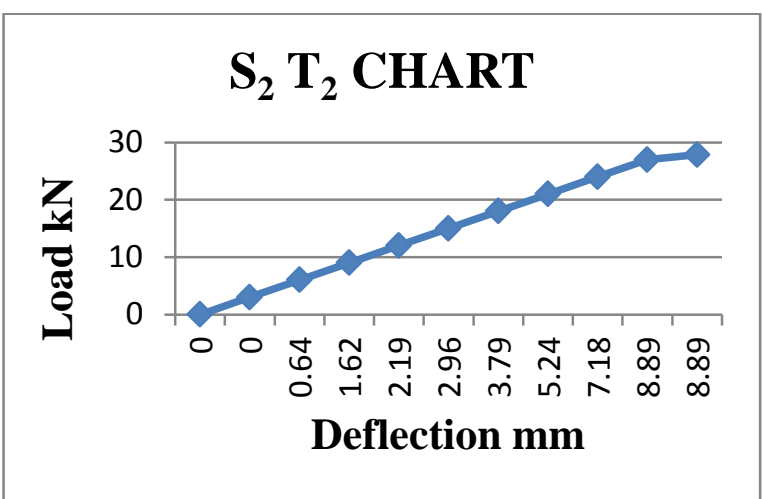

Figure 10 Deflection of slab $S_{2} T_{2}$ CHART

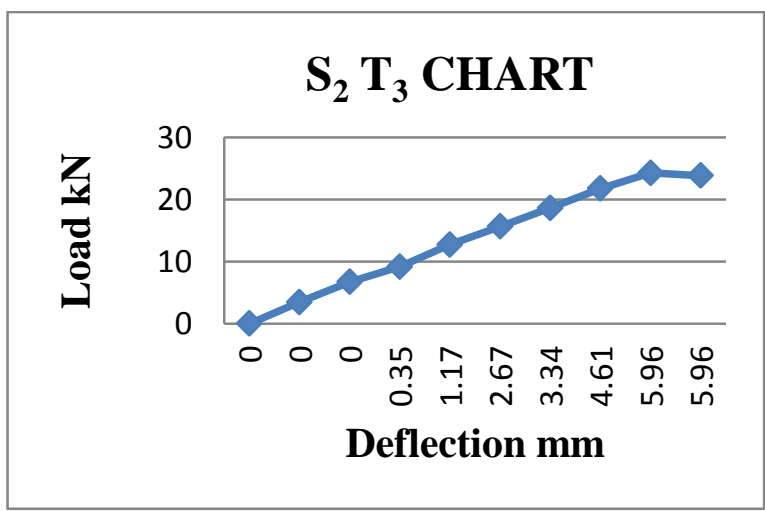

Figure 11 Deflection of slab $S_{2} T_{3}$ CHART

\section{CONCLUSION}

The following conclusions can be drawn on the outcomes of this observe:

From the experimental outcomes, it's miles observed that

1. The unit weight of lightweight concrete is 1603.45 for S2 specimens (zero,050\%)

2. The cube compressive energy is eight,590 N/ mm2 at 28 days had been able to withstand the weight partition

three.Flexural prism electricity is three,440 N/ mm2 at 28 days offers higher flexural electricity

four. Impact Test slab (S2) for five punches $1.1 \mathrm{~mm}$ crack initiation and crack the stop of the two.Three received a larger than normal concrete punching shear values indicate higher and bending behavior

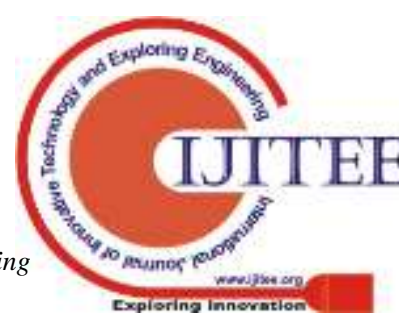


five. For different loading conditions slab specimens had been tested and the values are tabulated, the results of the observerd that the slab can withstand in opposition to the bending, shear diagonal and area

6. The impact strength balance ensueres partition for nailing and different varieties of unexpected load generated by means of human movement

\section{REFERENCES}

1. Brady, K.C \& Jones, M.R (2001) .Specification for Foamed Concrete

2. Chen, Y. And Zhang.Q (2009) Manufacturing generation of porous cement concrete for dual carriageway creation

3. Chris P.Pantelides, Brandon Ruifen T.Besser and Liu (2012) One manner to lightweight concrete shear conduct of bolstered bars

4. Dhawal Desai-IIT Bombay (2000) Development of Lightweight Concrete

5. E. K. K. Nambiar and K. Ramamurthy, "Air-emptiness foam concrete characterization," Cement Concrete Research, vol. 37, no. 2, pp. 221-230 2007

6. E. R. Domingo, "Introduction to autoclaved aerated concrete which includes design requirements using the power of design," M.S. Thesis, Kansas State University, Manhattan, Kansas, 2008

7. Gambhir, M.L. (2004) .Concrete Technology. New Delhi: Tata McGraw Hill

8. "A Guide to Structural Lightweight Aggregate Concrete". ACI 213R-87, American Concrete Institute, Detroit, Michigan. 1987

9. Husain Al-Naseer khaiat and Haque (1999) The electricity and durability of light-weight concrete

10. J. Newman, B. S. Choo, and P. Owens, Advanced Concrete Technology Processes, Elsevier Ltd., 2003, component 2, pp. 2 / 7-2 / nine

11. Aghaee Kamran, Mohammad Foroughi, (2000) Development of Lightweight Concrete Partition Using Textile Waste

12. K. J. Byun, H. W. Song, and S. S. Park, "Development of structural light-weight foamed concrete the usage of polymer foam agent," ICPIC 98th, 1998

13. E.P. Thirteen. Kearsley, Wainwright P.J. The have an effect on of porosity at the power of foamed concrete // Cement and Concrete Research 32 (2002) 233-239

14. Leming, M.L. "Lightweight Concrete Creep and Shrinkage". Department of Civil Engineering, North Carolina State University in Raleigh, North Carolina. April sixteen, 1990

15. L. B. Yen, "Study of the access of water into the foamed concrete," M.S. Thesis, National University of Singapore, 2006

16. M.S.Shetty Concrete Technology, Chand publication, version (2006)

17. M. O. Mydin and C. Y. Wang, "The mechanical houses of foamed concrete uncovered to excessive temperatures," Construction and Building Materials, vol. 26, no. 1, pp. 638-654, 2012

18. Narayanan, N. \& Ramamurthy.K (2000) .Structure and nature Aerated Concrete. 22, No.5, pp 321 -. 329

19. O. Richard, M. Ramli and K. M. Al Shareem, "Experimental manufacturing of light-weight foamed concrete sustainable," British Journal of Applied Science \& Technology, vol. 3, no. Four, pp. 1-12, 2013

20. "Standard Practice for Selecting The share of Structural Lightweight Concrete". ACI 211.2-ninety eight, American Concrete Institute, Detroit, Michigan. 1998

21. S.Rooyen, "Structural lightweight aerated concrete," M.S. Thesis, Stellenbosch University, 2013
22. T. Wenling, L. Liyuan, Z. Xiaoyan, Z. Mingjie, and W. Nana, "foamed concrete packages in street engineering," in Proc. International Conference on Transportation Engineering, 2009, p. 2114-2119 